\title{
Immune cell populations and cytokine production in spleen and mesenteric lymph nodes after laparoscopic surgery versus conventional laparotomy in mice
}

\author{
Moehrlen, Ueli ; Lechner, Anja ; Bäumel, Monika ; Dostert, Karin ; Röhrl, Johann ; Meuli, Martin ; \\ Männel, Daniela N ; Hamacher, Jürg
}

\begin{abstract}
PURPOSE: There is evidence that open as well as minimally invasive abdominal surgery impair post-operative innate and acquired immune function. To compare the impact of these approaches as well as the one of different peritoneal gas exposures on immune function, we investigated cellular as well as cytokine-based immune parameters in mesenteric lymph nodes and the spleen postoperatively. METHODS: Mice $(n=26)$ were randomly assigned to the 4 study groups: (1) sham controls undergoing anesthesia alone, (2) laparotomy, and (3) air, or (4) carbon dioxide pneumoperitoneum. Mice were sacrificed $48 \mathrm{~h}$ after the intervention, and their spleens and mesenteric lymph nodes were harvested. Cytokine production (TNF-, IL-6, IL-10, and IFN-), splenic T cell subpopulations (cytotoxic T cells, $\mathrm{T}$ helper cells, and regulatory T cells) were analyzed. RESULTS: TNF- production of splenocytes $16 \mathrm{~h}$ after ex vivo lipopolysaccharides (LPS) stimulation was significantly increased in the laparotomy group compared to all other groups. In contrast, TNF- production of lymph node cells and IL- 6 production of splenocytes after ex vivo LPS stimulation did not differ significantly between the groups. The numbers of regulatory $\mathrm{T}$ cells (Treg) in the spleen differed between groups. A significant reduction in Treg cell frequency was detected in the $\mathrm{CO}(2)$ insufflation group compared to the laparotomy and the air insufflation group. CONCLUSION: Our findings demonstrate a distinct difference in immune effector functions and cellular composition of the spleen with regard to splenic TNF- production and increased numbers of Treg cells in the spleen. These findings are in line with a higher peritoneal inflammatory status consequent to peritoneal air rather than $\mathrm{CO}(2)$ exposure. Treg turned out to be key modulators of postoperative dysfunction of acquired immunity.
\end{abstract}

DOI: https://doi.org/10.1007/s00383-012-3070-1

Posted at the Zurich Open Repository and Archive, University of Zurich

ZORA URL: https://doi.org/10.5167/uzh-74227

Journal Article

Published Version

Originally published at:

Moehrlen, Ueli; Lechner, Anja; Bäumel, Monika; Dostert, Karin; Röhrl, Johann; Meuli, Martin; Männel, Daniela N; Hamacher, Jürg (2012). Immune cell populations and cytokine production in spleen and mesenteric lymph nodes after laparoscopic surgery versus conventional laparotomy in mice. Pediatric Surgery International, 28(5):507-513.

DOI: https://doi.org/10.1007/s00383-012-3070-1 


\title{
Immune cell populations and cytokine production in spleen and mesenteric lymph nodes after laparoscopic surgery versus conventional laparotomy in mice
}

\author{
Ueli Moehrlen · Anja Lechner • Monika Bäumel • \\ Karin Dostert • Johann Röhrl • Martin Meuli • \\ Daniela N. Männel · Jürg Hamacher
}

Accepted: 5 March 2012/Published online: 17 March 2012

(C) Springer-Verlag 2012

\begin{abstract}
Purpose There is evidence that open as well as minimally invasive abdominal surgery impair post-operative innate and acquired immune function. To compare the impact of these approaches as well as the one of different peritoneal gas exposures on immune function, we investigated cellular as well as cytokine-based immune parameters in mesenteric lymph nodes and the spleen postoperatively.

Methods Mice $(n=26)$ were randomly assigned to the 4 study groups: (1) sham controls undergoing anesthesia alone, (2) laparotomy, and (3) air, or (4) carbon dioxide pneumoperitoneum. Mice were sacrificed $48 \mathrm{~h}$ after the intervention, and their spleens and mesenteric lymph nodes were harvested. Cytokine production (TNF- $\alpha$, IL-6, IL-10,
\end{abstract}

U. Moehrlen, A. Lechner, D. N. Männel and J. Hamacher contributed equally to the work.

U. Moehrlen $(\bowtie) \cdot$ M. Meuli

Department of Pediatric Surgery, University Children's Hospital Zurich, Steinwiesstr. 75, 8032 Zurich, Switzerland

e-mail: ueli.moehrlen@kispi.uzh.ch

A. Lechner · M. Bäumel · K. Dostert · J. Röhrl · D. N. Männel Faculty of Medicine, Institute of Immunology,

University of Regensburg, Regensburg, Germany

J. Hamacher

Pulmonary Division, University Hospital,

Inselspital, University of Bern, Bern, Switzerland

J. Hamacher

Pulmonary Medicine, Lindenhofspital, Bern, Switzerland

J. Hamacher

Pulmonary Medicine, Saarland University,

Homburg/Saar, Germany and IFN- $\gamma$ ), splenic $\mathrm{T}$ cell subpopulations (cytotoxic $\mathrm{T}$ cells, $\mathrm{T}$ helper cells, and regulatory $\mathrm{T}$ cells) were analyzed. Results TNF- $\alpha$ production of splenocytes $16 \mathrm{~h}$ after ex vivo lipopolysaccharides (LPS) stimulation was significantly increased in the laparotomy group compared to all other groups. In contrast, TNF- $\alpha$ production of lymph node cells and IL-6 production of splenocytes after ex vivo LPS stimulation did not differ significantly between the groups. The numbers of regulatory $\mathrm{T}$ cells (Treg) in the spleen differed between groups. A significant reduction in Treg cell frequency was detected in the $\mathrm{CO}_{2}$ insufflation group compared to the laparotomy and the air insufflation group. Conclusion Our findings demonstrate a distinct difference in immune effector functions and cellular composition of the spleen with regard to splenic TNF- $\alpha$ production and increased numbers of Treg cells in the spleen. These findings are in line with a higher peritoneal inflammatory status consequent to peritoneal air rather than $\mathrm{CO}_{2}$ exposure. Treg turned out to be key modulators of postoperative dysfunction of acquired immunity.

Keywords Laparoscopy · Laparotomy ·

Pneumoperitoneum - Immune function - Mouse model .

Lymphocyte subsets · T-lymphocytes · Regulatory ·

Cytokines

\section{Introduction}

Minimally invasive abdominal surgery better preserves postoperative local and systemic immune functions compared to open abdominal surgery $[1,7,8,30]$. Animal models revealed increased inflammation [34], impaired delayed-type sensitivity [8, 30, 32], increased metastatic tumor spread [8], and possibly more scarring after open 
abdominal surgery compared to minimal invasive abdominal surgery [10]. A number of clinical studies are in line with those experimental results. For instance, in contrast to open surgery, laparoscopic cholecystectomy caused less systemic immune impairment in terms of delayed hypersensitivity, interleukin-6 (IL-6) production, and white blood cell count $[4,11,17,18]$.

Several mechanisms may account for these observations: The different trauma severities associated with laparoscopic versus open surgery with inherent local biochemical alterations such as eicosanoid, cytokine, and growth factor liberation, hemorrhage and thrombocoagulative processes, cell and tissue edema and destruction. Similarly, different patterns of ensuing inflammatory, necrotic, or apoptotic cascades $[6,20]$ are likely to contribute to the more favorable, i.e., "milder", repair mechanisms characterizing minimally invasive interventions.

As a first line of defense, macrophages and polymorphonuclear granulocytes (PMN) are of main importance to protect the body from microorganisms. Macrophages, abundant present intraperitoneal defense cells, are key effectors and orchestrators of innate and acquired immunity [13]. They release different cytokines and mediators to control key events in the initiation and resolution of inflammation. PMN are the first blood-born nucleated cells to populate a site of acute tissue alteration [35]. After an inflammatory stimulus, PMN enter the peritoneal cavity in high numbers and become potent effectors of the first line of defense. Using a fluorescent cell tracer, we recently showed that about three times more PMN enter from the blood compartment into the peritoneum and undergo significantly less apoptosis when abdominal air insufflation is performed in comparison to $\mathrm{CO}_{2}$ insufflation [23]. PMN have the shortest half-life time among leukocytes and rapidly die by apoptosis $[9,27]$. All apoptotic cells are quickly removed by phagocytic cells such as macrophages [28]. It is widely accepted that macrophages, by phagocytosing apoptotic cells, act in an anti-inflammatory way [19]. As peritoneal macrophages do not undergo apoptosis in the peritoneal cavity, but instead migrate to the draining lymph nodes for apoptosis [3], immune regulation might also occur in remote tissues.

The most commonly used gas for peritoneal insufflation, $\mathrm{CO}_{2}$ has been implicated as a factor leading to compromised intraperitoneal immunity. In vitro, macrophages produce significantly less TNF- $\alpha$ and IL- 1 when incubated in $\mathrm{CO}_{2}$ compared to air or helium [36]. Following $\mathrm{CO}_{2}$ pneumoperitoneum a $\mathrm{pH}$ drop decreased cytokine production by macrophages, and lactate inhibited LPS-stimulated cytokine release from peritoneal macrophages [21]. Ambient air with its increased partial oxygen pressure may additionally increase inflammatory processes through oxidative stress [15].
In order to compare the impact of the different operative approaches and peritoneal gas exposures on immune functions, we investigated both cytokine production and cellular components locally as well as systemically by measuring immune parameters in the mesenteric lymph nodes as well as in the spleen. We used a relatively late time point of $48 \mathrm{~h}$ post-intervention, as delayed-type hypersensitivity in mice was suppressed at that time point after laparotomy, but not after laparoscopy [8]. Our aim was to assess eventual differences in cytokine patterns and $\mathrm{T}$ cell subpopulations (cytotoxic $\mathrm{T}$ cells, $\mathrm{T}$ helper cells and regulatory $\mathrm{T}$ cells) after an air versus $\mathrm{CO}_{2}$ pneumoperitoneum. Ex vivo cell stimulation assays and fluorescenceactivated cell scanning (FACS) analysis of lymphocyte subpopulations in the immune compartments of mesenteric lymph nodes and spleen were used.

\section{Materials and methods}

\section{Animals}

Female NMRI mice (Harlan Winkelmann, Borchen, Germany) weighing $27 \pm 1.5 \mathrm{~g}$ (mean $\pm \mathrm{SD}$ ) were used for all experiments. Mice were kept specific pathogen-free and allowed access to food and water ad libitum throughout the study. All experimental protocols were approved by the local review boards for animal care and are in accordance with the Helsinki Declaration. All animals were allowed to acclimate for a minimum of 7 days before experimental use.

\section{Experimental setting}

Mice were randomly assigned to one of the 4 groups: sham controls undergoing the same anesthesia procedure without any abdominal surgery (further referred as "control"), laparotomy ("laparotomy"), air pneumoperitoneum ("air") and carbon dioxide pneumoperitoneum (" $\mathrm{CO}_{2}$ "). All mice were anesthetized in an induction chamber using $4 \%$ halothane in $\mathrm{O}_{2}$ and were transorally intubated for mechanical ventilation using a wire guide [12] and an operational microscope with $2 \%$ isoflurane in $\mathrm{O}_{2}$ during the whole procedure. Mechanical ventilation was performed using a Hugo Sachs Harvard Apparatus mouse ventilator (Hugo Sachs-Harvard Instruments, March-Hugstetten, Germany) with a tidal volume of $8 \mu \mathrm{l} /$ $\mathrm{g}$ body weight and a frequency of $200-240 / \mathrm{min}$. Mice in the control group were anesthetized and kept intubated for $90 \mathrm{~min}$. In the laparotomy group, a midline laparotomy was performed and maintained for $90 \mathrm{~min}$ until closure in a two layer technique using Vicryl 4.0 (Ethicon, Hamburg, Germany) running suture for the peritoneum and 
staples for the skin. Mice in the air and $\mathrm{CO}_{2}$ group were insufflated with the appropriate gas with $10 \mathrm{mmHg}$ pressure using an Olympus laparoscopic insufflator (Olympus UHI-1 high flow insufflator, Olympus Volketswil, Switzerland) through an 18 gauge arterial catheter (Abbocath) inserted into the peritoneal cavity through the right lower abdominal wall. The pneumoperitoneum was maintained for $90 \mathrm{~min}$, after which the abdomen was decompressed and the catheter removed. All animals were kept on a warming mat.

Mice were sacrificed $48 \mathrm{~h}$ after surgery (control: $n=6$; laparotomy: $n=7$; air: $n=6$; $\mathrm{CO}_{2}: n=7$ ).

After sacrifice using a $\mathrm{CO}_{2}$ chamber, the spleens and mesenteric lymph nodes were harvested. All cell isolation steps were performed on ice or, where not possible, at $+4{ }^{\circ} \mathrm{C}$.

The cell suspensions were prepared by gently pushing splenic tissue through a disposable cell strainer (BD Biosciences) and the cells were pelleted by centrifugation at $300 \times g$ for $12 \mathrm{~min}$. The supernatant was removed, and the cells were resuspended in $1 \mathrm{ml}$ RPMI 1640 supplemented with penicillin $(100 \mathrm{U} / \mathrm{ml})$ and streptomycin $(100 \mu \mathrm{g} / \mathrm{ml})$, but without FCS. The cells were counted with a Neubauer hemocytometer, and viability was determined using Trypan blue exclusion.

\section{Antibodies and reagents}

The following antibodies were used for flow cytometry: Hamster anti-mouse CD3 $\varepsilon$ (clone 145.2C11, BD Biosciences, Heidelberg, Germany), rat anti-mouse CD4 (clone RM4-5, BD Biosciences), rat anti-mouse CD8 $\alpha$ (clone 53-6.7, BD Biosciences), rat anti-mouse B220 (clone RA36B2, BD Biosciences) rat anti-mouse CD11c (clone N418, AbD Serotec, Düsseldorf, Germany), rat anti-mouse CD62L (clone MEL-14, BD Biosciences), hamster antimouse CD11b (clone M 1/70, BD Biosciences), rat antimouse MHC II (clone M5/114.15.2, Miltenyi Biotech, Mönchengladbach, Germany), rat anti-mouse Foxp3 (clone FJK-16s, Natutec, Frankfurt, Germany), rat anti-mouse CD25 (clone PC61, BD Biosciences), and hamster antimouse CD28 (clone 37.51, BD Biosciences). PE labeled isotype control $\mathrm{IgG}$ was purchased from BD Biosciences.

Flow cytometry and cell analysis

Cells were incubated with the appropriate antibodies in staining buffer (PBS containing $2 \%$ FCS). Data were collected on the LSR II flow cytometer (BD Biosciences) and analyzed using the DIVA software (BD Biosciences). All staining profiles were based on live-gated cells, as determined by forward and sideward scatter properties.
Determination of cytokine production of splenocytes and mesenteric lymph node cells

For the determination of TNF- $\alpha$, IL-6, IL-10 splenocytes and mesenteric lymph node cells were stimulated with LPS (10 ng/ml; E. coli, serotype O111:B4, Sigma-Aldrich, München, Germany). For the determination of INF- $\gamma$ the splenocytes and mesenteric lymph node cells were stimulated by $\alpha-\mathrm{CD} 3$ and $\alpha-\mathrm{CD} 28$. Cell culture supernatants were collected after $16 \mathrm{~h}$ of culture and preserved for further analysis at $-20^{\circ} \mathrm{C}$. For $\mathrm{T}$ cell stimulation, splenocytes were stimulated in vitro with plate bound antiCD3 $\varepsilon$ antibody $(5 \mu \mathrm{g} / \mathrm{ml})$ and soluble anti- CD28 antibody $(2 \mu \mathrm{g} / \mathrm{ml})$ for $16 \mathrm{~h}$. Supernatants were collected for ELISA. TNF- $\alpha$, IL-6, IL-10, and IFN- $\gamma$ protein quantification was performed with DUO-ELISA kits (R\&D Systems) following the manufacturer's instructions. The lower limit of detection for the cytokines was $20 \mathrm{pg} / \mathrm{ml}$.

Statistical analysis

Analyses were performed with GraphPad Prism, version 3.0 (GraphPad Software, Inc., San Diego, USA), giving mean \pm SD or, if not normally distributed, median and range. Normally distributed variables were analyzed by ANOVA, followed by Dunnett post hoc test or by Bonferroni correction where adequate. A $p$ value $\leq 0.05$ was considered significant.

\section{Results}

Determination of cell numbers in the spleen and mesenteric lymph nodes

Neither the number of splenocytes (control group: $55.5 \pm$ $35.5 \times 10^{6}$ cells, laparotomy group: $44.5 \pm 23.4 \times 10^{6}$ cells, air insufflation group: $61.1 \pm 32.0 \times 10^{6}$ cells and $\mathrm{CO}_{2}$ insufflation group: $75.1 \pm 29.3 \times 10^{6}$ cells) nor the number of lymph node cells (control group: $23.6 \pm 6.9 \times$ $10^{6}$ cells, laparotomy group: $24.8 \pm 5.0 \times 10^{6}$ cells, air insufflation group: $28.9 \pm 15.8 \times 10^{8}$ cells and $\mathrm{CO}_{2}$ insufflation group: $16.9 \pm 4.6 \times 10^{6}$ cells) differed significantly when analyzed $48 \mathrm{~h}$ after the intervention.

Cytokine production of splenocytes and mesenteric lymph node cells in response to LPS stimulation

TNF- $\alpha$ production of splenocytes after ex vivo LPS stimulation was significantly increased in the laparotomy group $(4.45 \pm 2.09 \mathrm{ng} / \mathrm{ml})$ compared to the control $(2.59 \pm 0.51$ $\mathrm{ng} / \mathrm{ml})$, the air insufflation $(2.41 \pm 0.94 \mathrm{ng} / \mathrm{ml})$ and the $\mathrm{CO}_{2}$ insufflation group $(1.73 \pm 0.44 \mathrm{ng} / \mathrm{ml} ; \quad p<0.01)$ 


\section{TNF production of splenocytes after LPS stimulation}

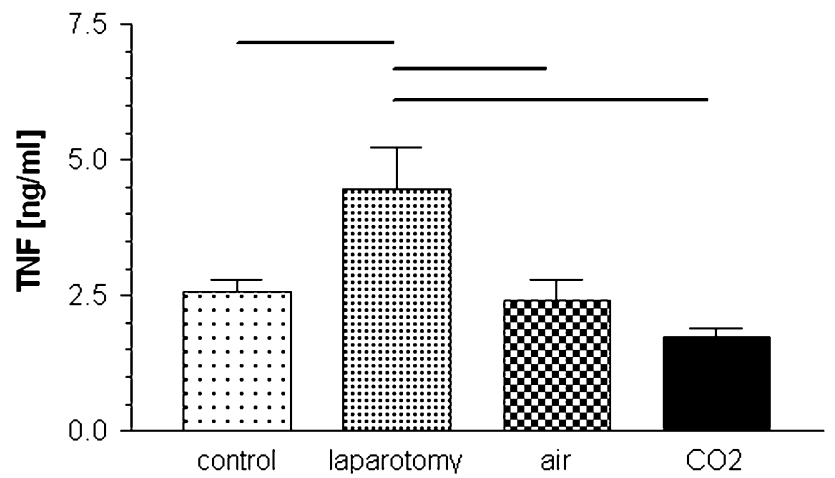

Fig. 1 Ex vivo TNF production of isolated splenocytes after LPS stimulation. Splenocytes were isolated from mice received either laparotomy (laparotomy) or laparoscopy (air or $\mathrm{CO}_{2}$ ) or anesthesia only (control). Cells were cultured in vitro in the presence of LPS $(10 \mathrm{ng} / \mathrm{ml})$ and supernatants were harvested after $16 \mathrm{~h}$. TNF production was determined by ELISA. Data represent the mean values $( \pm$ SEM, bar $p<0.05)$

(Fig. 1). In contrast, TNF- $\alpha$ production of lymph node cells after ex vivo LPS stimulation did not differ significantly between the groups (control $0.40 \pm 0.43 \mathrm{ng} / \mathrm{ml}$; laparotomy $0.44 \pm 0.20 \mathrm{ng} / \mathrm{ml}$; air insufflation $0.36 \pm 0.24 \mathrm{ng} /$ $\mathrm{ml} ; \mathrm{CO}_{2}$ insufflation $0.26 \pm 0.15 \mathrm{ng} / \mathrm{ml}: p=0.73$ ).

Also, IL-6 production of ex vivo LPS stimulated splenocytes did not differ significantly between groups. The IL-6 concentration was $0.28 \pm 0.30 \mathrm{pg} / \mathrm{ml}$ in the control group, $0.47 \pm 0.35 \mathrm{pg} / \mathrm{ml}$ in the laparotomy group, $0.28 \pm 0.27 \mathrm{pg} / \mathrm{ml}$ in the air insufflation group and $0.31 \pm 0.41 \mathrm{pg} / \mathrm{ml}$ in the carbon dioxide insufflation group $(p=0.68)$. IL-6 production of ex vivo LPS stimulated lymph node cells was below the detection limit (ELISA detection limit $20 \mathrm{pg} / \mathrm{ml}$ ).

IL-10 production of splenocytes did not differ between groups after ex vivo LPS stimulation. The IL-10 concentration after LPS stimulation was $0.43 \pm 0.44 \mathrm{ng} / \mathrm{ml}$ in the control group, $0.34 \pm 0.20 \mathrm{ng} / \mathrm{ml}$ in the laparotomy group, $0.42 \pm 0.47 \mathrm{ng} / \mathrm{ml}$ in the air insufflation group and $0.29 \pm 0.11 \mathrm{ng} / \mathrm{ml}$ in the $\mathrm{CO}_{2}$ insufflation group $(p=0.64)$. IL-10 production of ex vivo LPS or combined anti-CD3 and anti-CD28 stimulated lymph node cells was below the detection limit (ELISA detection limit $20 \mathrm{pg} / \mathrm{ml}$ ).

Cytokine production by $\mathrm{T}$ cells

After combined anti-CD3 and anti-CD28 stimulation, we observed no differences in IL-10 secretion by splenocytes. The IL-10 concentration was $1.96 \pm 0.86 \mathrm{ng} / \mathrm{ml}$ in the control group, $1.51 \pm 0.86 \mathrm{ng} / \mathrm{ml}$ in the laparotomy group, $1.63 \pm 0.59 \mathrm{ng} / \mathrm{ml}$ in the air insufflation group and $1.82 \pm 0.42 \mathrm{ng} / \mathrm{ml}$ in the $\mathrm{CO}_{2}$ insufflation group $(p=0.67)$.
In addition, IFN- $\gamma$ production of splenocytes and lymph node cells after ex vivo combined anti-CD3 and anti-CD28 stimulation, did not differ significantly. The IFN- $\gamma$ production of stimulated splenocytes was $119.7 \pm 47.7 \mathrm{ng} / \mathrm{ml}$ in the control group, $124.9 \pm 49.9 \mathrm{ng} / \mathrm{ml}$ in the laparotomy group, $125.0 \pm 28.8 \mathrm{ng} / \mathrm{ml}$ in the air insufflation group, and $169.5 \pm 89.7 \mathrm{ng} / \mathrm{ml}$ in the $\mathrm{CO}_{2}$ insufflation group $(p=0.40)$.

The IFN- $\gamma$ production of stimulated lymph node cells was $73.9 \pm 34.6 \mathrm{ng} / \mathrm{ml}$ in the control group, $63.3 \pm 60.8 \mathrm{ng} / \mathrm{ml}$ in the laparotomy group, $66.4 \pm 79.4 \mathrm{ng} / \mathrm{ml}$ in the air insufflation group, and $54.7 \pm 31.6 \mathrm{ng} / \mathrm{ml}$ in the $\mathrm{CO}_{2}$ insufflation group $(p=0.40)$.

\section{Splenic T cell subpopulations}

There was also no difference in the frequency of cytotoxic $\mathrm{T}$ cells $\left(\mathrm{CD}^{+}, \mathrm{CD}^{+}\right)$in the spleen after the different procedures (control: $9.81 \pm 2.04 \%$; laparotomy: $10.73 \pm 3.65$ $\%$; air insufflation: $8.17 \pm 1.54 \% ; \mathrm{CO}_{2}$ insufflation: $8.08 \pm 2.13 \% ; p=0.29$ ). Also, no difference was found in the numbers of activated cytotoxic $\mathrm{T}$ cells $\left(\mathrm{CD} 8^{+}, \mathrm{CD} 3^{+}\right.$, $\mathrm{CD}^{2} \mathrm{~L}^{-}$): control: $7.92 \pm 2.59 \%$; laparotomy: $8.31 \pm$ $5.20 \%$; air insufflation: $7.14 \pm 2.61 \%$; $\mathrm{CO}_{2}$ insufflation: $7.62 \pm 1.67 \%$; $(p=0.95)$. There was also no difference in Thelper cells $\left(\mathrm{CD}^{+}, \mathrm{CD}^{+}\right)$in the spleen after the different procedures (control: $29.92 \pm 2.89 \%$; laparotomy: $31.42 \pm$ $4.08 \%$; air insufflation: $28.10 \pm 4.68 \% ; \mathrm{CO}_{2}$ insufflation: $35.36 \pm 6.94 \% ; p=0.15$ ). Also no difference was found in activated $\mathrm{T}$ helper cells $\left(\mathrm{CD} 4^{+}, \mathrm{CD}^{+}, \mathrm{CD} 2 \mathrm{~L}^{-}\right)$in the spleen (control: $8.86 \pm 1.83 \%$; laparotomy: $7.70 \pm$ $1.21 \%$; air insufflation: $9.02 \pm 2.00 \%$; $\mathrm{CO}_{2}$ insufflation: $7.93 \pm 1.19 \% ;(p=0.48))$. No difference was found in the ratios of Thelper cells to Tregs ( $p=0.32$ ) and of activated T helper cells to Tregs ( $p=0.07)$.

Regulatory T cells (Treg) were phenotypically defined as $\mathrm{CD} 4^{+} \mathrm{CD} 25^{\mathrm{hi}}$ cells expressing intracellular Foxp3. The average proportion of freshly isolated Treg cells differed significantly between groups $(p<0.005)$. The proportion of Treg in the control group were $7.23 \pm 0.97 \%$, in the laparotomy group $9.29 \pm 1.17 \%$, in the air insufflation group $9.38 \pm 0.69 \%$, and in the $\mathrm{CO}_{2}$ group $7.90 \pm 0.44 \%$. Significant differences could be demonstrated between the $\mathrm{CO}_{2}$ insufflation group compared to the laparotomy $(p<0.05)$ and the air insufflation group $(p<0.05)$ (Fig. 2a, b).

\section{Discussion}

Trauma affects the immune system at different levels. At the site of tissue injury, the local cytokine secretion activates residing phagocytes and recruits immune cells in secondary lymphoid organs, e.g., the spleen and the local 

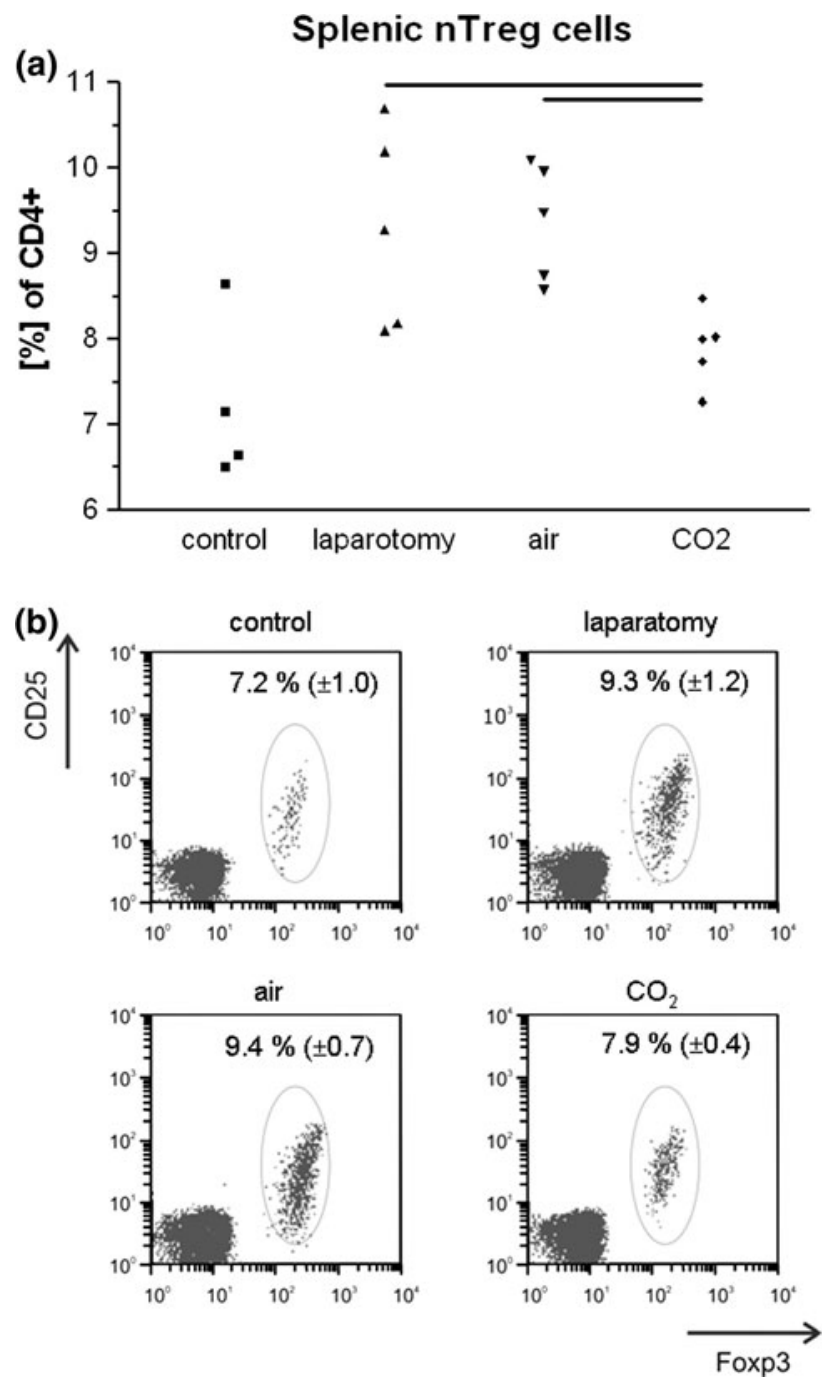

Fig. 2 a Frequency of Treg cells isolated from the spleen was significantly increased after abdominal air exposure compared to abdominal $\mathrm{CO}_{2}$ exposure. Splenocytes were isolated from mice received either laparotomy (laparotomy) or laparoscopy (air or $\mathrm{CO}_{2}$ ) or anesthesia only (control), stained with antibodies specific for CD3, CD4, CD25 and Foxp3 and analyzed by flow cytometry. In a the proportion of $\mathrm{CD}^{+}, \mathrm{CD}^{+}, \mathrm{CD} 25^{+}$and $\mathrm{Foxp}^{+}$is depicted. Data represent the mean $( \pm \mathrm{SEM}$; bar $p<0.05)$. b A representative analysis of splenic Treg cells for each surgery group is shown

lymphatic system. The activation of the immune system is accompanied by effector functions like phagocytosis and cytokine production of macrophages and neutrophils, and by a shift of the Teff/Treg cell balance leading to an immune suppressive status [33, 37]. It was demonstrated that the magnitude of the insult, the resulting immune response, and the consequent susceptibility to infection or sepsis are directly proportional [5].

After an inflammatory stimulus both the innate and acquired immunity are involved in host defense. The initial defense reaction after an inflammatory stimulus of the peritoneal cavity is the activation of PMN, peritoneal macrophages, natural killer cells, and $\gamma \delta \mathrm{T}$ cells. The orchestration of such a response is complex and further includes the surface cell layer in the abdominal cavity, i.e., peritoneal mesothelial cells, and the underlying capillary network. In addition to tissue trauma, operative time, or blood loss [29], cytokines like interleukin-6 (IL-6) may activate peritoneal mesothelial cells that induce a number of chemokines recruiting cells of the innate immune system into the peritoneal cavity [25]. These early inflammatory events enable the successful transition from innate to acquired immunity.

TNF and IL- 6 are produced initially after tissue trauma by peripheral blood monocytes and tissue macrophages. These cytokines are critically involved in the recruitment of immune cells to the site of tissue damage in order to resolve the inflammation. Circulating TNF levels usually peak between 12 and $24 \mathrm{~h}$ after the initial traumatic event. TNF together with IL-1 are responsible for acute symptoms of inflammation like fever and tachycardia [16]. Jacobi et al. [14] showed a more moderate increase of TNF plasma levels after laparoscopy compared to laparotomy. Prolonged and excessive IL-6 elevations are associated with increased morbidity and mortality [2].

In the present study we demonstrated a higher TNF release, but no significant difference in IL-6 and IL-10 production from splenocytes after LPS stimulation ex vivo $48 \mathrm{~h}$ after abdominal intervention in the laparotomy group compared to all other study groups, astonishingly also to the air insufflation group. These findings emphasize that systemic immunity is differentially affected by tissue trauma. Especially $\mathrm{CO}_{2}$ insufflation showed no difference to air in regard to systemic TNF production. This stands in sharp contrast to local peritoneal TNF production which is increased in non-stimulated peritoneal macrophages after in vivo air exposure of the peritoneal cavity [22]. One may hypothesize that for splenocyte stimulation tissue trauma is more relevant than the type of peritoneal gas exposure and its consecutive inflammatory response. The different splenic TNF production also stands in contrast to the equal TNF production of mesenteric lymph node cells at $48 \mathrm{~h}$ after surgery. An explanation for this finding may be the late time point investigated.

The analysis of splenic cells showed no difference in both cytotoxic $\mathrm{T}$ cells or activated cytotoxic $\mathrm{T}$ cells in regard to the method of surgery. Also neither splenic $\mathrm{T}$ helper cells, nor activated splenic $\mathrm{T}$ helper cells showed any significant difference between the compared groups. However, we detected significantly higher splenic Treg cell proportions in both the laparotomy and the air insufflation group if compared to $\mathrm{CO}_{2}$ insufflation.

Treg cells are characterized by the expression of the IL-2 receptor alpha chain (CD25) and the transcription factor 
FoxP3. These cells help to restrict overshooting of immune reactions and, therefore, prevent autoimmunity [26]. Increasing numbers of Treg cells has been observed in response to surgical trauma [31]. Under trauma conditions the increase in Treg cells corresponds with the immune suppression [24, 37]. In line with the fact that the Treg cell compartment is extended after trauma and sepsis [37] there was no difference between the $\mathrm{CO}_{2}$ insufflation and the sham anesthesia control group. The findings suggest that both groups with air exposure of the peritoneal cavity have more pronounced immune alteration, a finding that was also observed in our former studies [22, 23]. This finding may closely be linked to the suppressed recall immunity in terms of delayed type hypersensitivity during the four postoperative days in mice exposed to laparotomy observed earlier [8].

When we looked for a potential mechanism leading to the increase in Treg cells in the laparotomy and air insufflation groups we monitored IL-10 secretion in re-stimulated splenocytes. IL-10 is a complex cytokine with important immunosuppressive effects. It blocks monocyte/ macrophage dependent $\mathrm{T}$-cell activation and antigen presentation and is therefore a strong suppressor of key cytokines such as TNF- $\alpha$, IL-1- $\beta$, IL-6, IL-12, and IFN- $\gamma$. IL-10 is critically involved in the Treg expansion in sepsis [37]. However, no difference was found between the groups in IL-10 production or secretion of splenic cells, neither after ex vivo LPS stimulation, nor after combined anti-CD3 and anti-CD28 stimulation. The reason for Treg cell expansion in the laparotomy and the air insufflation group needs further investigation.

In conclusion, splenocytic TNF production was increased after laparotomy compared to all other groups suggesting a difference in splenocytic cell reaction depending on the severity of surgical tissue trauma.

Splenic Tregs differed significantly after surgery, underlining that peritoneal air exposure, as result of laparotomy or air insufflation, triggers a more pronounced postoperative immuno-suppression. The impact of such pronounced immune deficiency after peritoneal air exposure may be a higher risk for perioperative complications e.g., infections, impaired wound healing, or tumour spread.

Conflict of interest The authors declare that they have no conflict of interest.

\section{References}

1. Allendorf JD, Bessler M, Whelan RL, Trokel M, Laird DA, Terry MB, Treat MR (1996) Better preservation of immune function after laparoscopic-assisted vs. open bowel resection in a murine model. Dis Colon Rectum 39:S67-S72

2. Baigrie RJ, Lamont PM, Kwiatkowski D, Dallman MJ, Morris PJ (1992) Systemic cytokine response after major surgery. Br J Surg 79:757-760
3. Bellingan GJ, Caldwell H, Howie SE, Dransfield I, Haslett C (1996) In vivo fate of the inflammatory macrophage during the resolution of inflammation: inflammatory macrophages do not die locally, but emigrate to the draining lymph nodes. J Immunol 157:2577-2585

4. Bessler M, Whelan RL, Halverson A, Treat MR, Nowygrod R (1994) Is immune function better preserved after laparoscopic versus open colon resection? Surg Endosc 8:881-883

5. Brune IB, Wilke W, Hensler T, Holzmann B, Siewert JR (1999) Downregulation of $\mathrm{T}$ helper type 1 immune response and altered pro-inflammatory and anti-inflammatory $\mathrm{T}$ cell cytokine balance following conventional but not laparoscopic surgery. Am J Surg 177:55-60

6. Chekan EG, Nataraj C, Clary EM, Hayward TZ, Brody FJ, Stamat JC, Fina MC, Eubanks WS, Westcott CJ (1999) Intraperitoneal immunity and pneumoperitoneum. Surg Endosc 13:1135-1138

7. Collet D, Vitale GC, Reynolds M, Klar E, Cheadle WG (1995) Peritoneal host defenses are less impaired by laparoscopy than by open operation. Surg Endosc 9:1059-1064

8. Gitzelmann CA, Mendoza-Sagaon M, Talamini MA, Ahmad SA, Pegoli W Jr, Paidas CN (2000) Cell-mediated immune response is better preserved by laparoscopy than laparotomy. Surgery 127:65-71

9. Glasser L, Fiederlein RL, Huestis DW (1985) Liquid preservation of human neutrophils stored in synthetic media at 22 degrees $\mathrm{C}$ : controlled observations on storage variables. Blood 66:267-272

10. Gutt CN, Oniu T, Schemmer P, Mehrabi A, Buchler MW (2004) Fewer adhesions induced by laparoscopic surgery? Surg Endosc 18:898-906

11. Halevy A, Lin G, Gold-Deutsch R, Lavi R, Negri M, Evans S, Cotariu D, Sackier JM (1995) Comparison of serum C-reactive protein concentrations for laparoscopic versus open cholecystectomy. Surg Endosc 9:280-282

12. Hamacher J, Arras M, Bootz F, Weiss M, Schramm R, Moehrlen U (2008) Microscopic wire guide-based orotracheal mouse intubation: description, evaluation and comparison with transillumination. Lab Anim 42:222-230

13. Jackson PG, Evans SR (2000) Intraperitoneal macrophages and tumor immunity: a review. J Surg Oncol 75:146-154

14. Jacobi CA, Ordemann J, Zieren HU, Volk HD, Bauhofer A, Halle E, Muller JM (1998) Increased systemic inflammation after laparotomy vs laparoscopy in an animal model of peritonitis. Arch Surg 133:258-262

15. Jacobi CA, Sabat R, Bohm B, Zieren HU, Volk HD, Muller JM (1997) Pneumoperitoneum with carbon dioxide stimulates growth of malignant colonic cells. Surgery 121:72-78

16. Jacobi J (2002) Pathophysiology of sepsis. Am J Health Syst Pharm 59(Suppl 1):S3-S8

17. Karayiannakis AJ, Makri GG, Mantzioka A, Karousos D, Karatzas G (1997) Systemic stress response after laparoscopic or open cholecystectomy: a randomized trial. Br J Surg 84:467-471

18. Kloosterman T, von Blomberg BM, Borgstein P, Cuesta MA, Scheper RJ, Meijer S (1994) Unimpaired immune functions after laparoscopic cholecystectomy. Surgery 115:424-428

19. Kurosaka K, Takahashi M, Watanabe N, Kobayashi Y (2003) Silent cleanup of very early apoptotic cells by macrophages. J Immunol 171:4672-4679

20. Lennard TW, Shenton BK, Borzotta A, Donnelly PK, White M, Gerrie LM, Proud G, Taylor RM (1985) The influence of surgical operations on components of the human immune system. Br J Surg 72:771-776

21. Mahiout A, Brunkhorst R (1995) Pyruvate anions neutralize peritoneal dialysate cytotoxicity. Nephrol Dial Transplant 10:391-394

22. Moehrlen U, Schwobel F, Reichmann E, Stauffer U, Gitzelmann CA, Hamacher J (2005) Early peritoneal macrophage function 
after laparoscopic surgery compared with laparotomy in a mouse mode. Surg Endosc 19:958-963

23. Moehrlen U, Ziegler U, Boneberg E, Reichmann E, Gitzelmann CA, Meuli M, Hamacher J (2006) Impact of carbon dioxide versus air pneumoperitoneum on peritoneal cell migration and cell fate. Surg Endosc 20:1607-1613

24. Ni CN, MacConmara M, Zang Y, Murphy TJ, Mannick JA, Lederer JA (2006) Enhanced regulatory T cell activity is an element of the host response to injury. J Immunol 176:225-236

25. Riese J, Niedobitek G, Lisner R, Jung A, Hohenberger W, Haupt W (2004) Expression of interleukin-6 and monocyte chemoattractant protein-1 by peritoneal sub-mesothelial cells during abdominal operations. J Pathol 202:34-40

26. Sakaguchi S, Ono M, Setoguchi R, Yagi H, Hori S, Fehervari Z, Shimizu J, Takahashi T, Nomura T (2006) Foxp3+ CD25+ $\mathrm{CD} 4+$ natural regulatory $\mathrm{T}$ cells in dominant self-tolerance and autoimmune disease. Immunol Rev 212:8-27

27. Savill J, Dransfield I, Hogg N, Haslett C (1990) Vitronectin receptor-mediated phagocytosis of cells undergoing apoptosis. Nature 343:170-173

28. Savill J, Fadok V, Henson P, Haslett C (1993) Phagocyte recognition of cells undergoing apoptosis. Immunol Today 14:131-136

29. Schwenk W, Jacobi C, Mansmann U, Bohm B, Muller JM (2000) Inflammatory response after laparoscopic and conventional colorectal resections-results of a prospective randomized trial. Langenbecks Arch Surg 385:2-9
30. Trokel MJ, Bessler M, Treat MR, Whelan RL, Nowygrod R (1994) Preservation of immune response after laparoscopy. Surg Endose 8:1385-1387

31. Vallina VL, Velasco JM (1996) The influence of laparoscopy on lymphocyte subpopulations in the surgical patient. Surg Endosc $10: 481-484$

32. Vittimberga FJ Jr, Foley DP, Meyers WC, Callery MP (1998) Laparoscopic surgery and the systemic immune response. Ann Surg 227:326-334

33. Wakefield CH, Carey PD, Foulds S, Monson JR, Guillou PJ (1993) Polymorphonuclear leukocyte activation. An early marker of the postsurgical sepsis response. Arch Surg 128:390-395

34. Watson RW, Redmond HP, McCarthy J, Burke PE, BouchierHayes D (1995) Exposure of the peritoneal cavity to air regulates early inflammatory responses to surgery in a murine model. Br J Surg 82:1060-1065

35. Watson RW, Rotstein OD, Nathens AB, Parodo J, Marshall JC (1997) Neutrophil apoptosis is modulated by endothelial transmigration and adhesion molecule engagement. J Immunol 158:945-953

36. West MA, Hackam DJ, Baker J, Rodriguez JL, Bellingham J, Rotstein OD (1997) Mechanism of decreased in vitro murine macrophage cytokine release after exposure to carbon dioxide: relevance to laparoscopic surgery. Ann Surg 226:179-190

37. Wisnoski N, Chung CS, Chen Y, Huang X, Ayala A (2007) The contribution of $\mathrm{CD} 4+\mathrm{CD} 25+\mathrm{T}$-regulatory-cells to immune suppression in sepsis. Shock 27:251-257 